\title{
Pengaruh Proses Rekrutmen dan Seleksi terhadap Kinerja Karyawan : Studi pada PT. Dian Bahari Sejati
}

\author{
Muhammad Darwis Meyandie Nasution \\ Universitas Merdeka Malang \\ Email : darwis@dianbaharisejati.com
}

\begin{abstract}
Based on the data processing hasi it is known that the selection in which the company has an influence on employee performance partially. The most dominant variable affecting the performance of employees, especially in PT. Dian Bahari Sejati is the selection, the reason for the selection of variables having the largest value of the regression coefficient when compared with variable recruitment, so that the second hypothesis can be said to be proven. Simultaneously, it is known that the process of recruitment and selection simultaneously have an influence on the performance of employees at PT. Dian Bahari Sejati.

The influence of variables $X_{I}$ ( recruitment) to variable $Y$ (company performance) indicated by the value of the correlation coefficient ( $r x y$ ) of 0.727 . While the $R$-square is 0.528 or $52.80 \%$, showing approximately $52.80 \%$ variable $Y$ ( the performance of the company's employees ) can be explained by the recruitment process variable $\left(X_{1}\right)$, or in practice it can be said that the contribution of the recruitment process $\left(X_{1}\right)$ to variable $Y($ performance of employees) is $52.80 \%$. The rest is influenced by other variables not examined. The influence of $\mathrm{X}_{2}$ ( selection) to variable $Y$ ( the performance of employees ) indicated by the value of the correlation coefficient ( $r$ xy) of 0.655 . While the $R$-square is 0.429 or $42.90 \%$, showing approximately $42.90 \%$ variable $Y$ ( the performance of the employee ) can be explained by the selection of variables $\left(X_{2}\right)$, or in practice it can be said that the contribution of selection $\left(X_{2}\right)$ to variable $Y$ (employee performance) is $42.90 \%$. The rest is influenced by other variables not examined.

The influence of variables $X_{1}$ ( recruitment) and $X_{2}$ ( selection) to variable $Y$ ( the performance of employees) indicated by the multiple correlation coefficient of 0.565 , while the $R$-square value is 0.319 or $31.90 \%$, showing approximately $31.90 \%$ variable $Y$ can be explained by the recruitment process variable $\left(X_{1}\right)$ and selection $\left(X_{2}\right)$ to variable $Y$ ( the performance of the employee ) is $31.90 \%$. The rest is influenced by other variables not examined. Or proposed hypothesis can be accepted or recruitment process and se ; of selection has a positive and significant effect on the performance of employees at PT. Dian Bahari Sejati.
\end{abstract}

Keywords : Process Recruitment, Selection and Performance

Abstrak

Berdasarkan hasil pengolahan data maka diketahui, bahwa seleksi yang ada dalam perusahaan mempunyai pengaruh terhadap kinerja karyawan secara parsial. Variabel yang paling dominan mempengaruhi kinerja karyawan khususnya pada PT. Dian Bahari Sejati adalah seleksi, alasannya karena variabel seleksi memiliki nilai koefisien regresi yang terbesar jika dibandingkan dengan variabel rekrutmen, sehingga hipotesis kedua dapat dikatakan terbukti. Secara simultan diketahui bahwa proses rekrutmen dan seleksi mempunyai pengaruh secara simultan terhadap kinerja karyawan pada PT. Dian Bahari Sejati.

Adanya pengaruh variabel $\mathrm{x}_{1}$ (proses rekrutmen) terhadap variabel y (kinerja perusahaan) yang ditunjukkan oleh nilai koefisien korelasi $\left(\mathrm{r}_{\mathrm{xy}}\right)$ sebesar 0,727. Sedangkan $r$-square adalah 0,528 atau 52,80\%, menunjukkan sekitar 52,80\% variabel y (kinerja karyawan perusahaan) dapat dijelaskan oleh variabel proses rekrutmen $\left(\mathrm{x}_{1}\right)$, atau secara praktis dapat dikatakan bahwa kontribusi proses rekrutmen $\left(\mathrm{x}_{1}\right)$ terhadap variabel $\mathrm{y}$ (kinerja karyawan) adalah 52,80\%. Sisanya dipengaruhi oleh variabel lain yang tidak diteliti. Adanya pengaruh variabel $\mathrm{x}_{2}$ (seleksi) terhadap variabel y (kinerja karyawan) yang ditunjukkan oleh nilai koefisien korelasi $\left(\mathrm{r}_{\mathrm{xy}}\right)$ sebesar 0,655. Sedangkan $r$-square adalah 0,429 atau 42,90\%, menunjukkan sekitar 42,90\% variabel y (kinerja karyawan) dapat dijelaskan oleh variabel seleksi $\left(\mathrm{x}_{2}\right)$, atau secara praktis dapat dikatakan bahwa kontribusi seleksi $\left(\mathrm{x}_{2}\right)$ terhadap variabel y (kinerja karyawan) adalah $42,90 \%$. sisanya dipengaruhi oleh variabel lain yang tidak diteliti.

Adanya pengaruh variabel $\mathrm{x}_{1}$ (proses rekrutmen) dan $\mathrm{x}_{2}$ (seleksi) terhadap variabel y (kinerja karyawan) yang ditunjukkan oleh nilai koefisien korelasi ganda sebesar 0,565, sedangkan nilai $r$-square adalah 0,319 atau $31,90 \%$, menunjukkan sekitar $31,90 \%$ variabel y dapat dijelaskan oleh variabel proses rekrutmen $\left(\mathrm{x}_{1}\right)$ dan seleksi $\left(\mathrm{x}_{2}\right)$ terhadap variabel y (kinerja karyawan) adalah 31,90\%. Sisanya dipengaruhi oleh variabel lain yang tidak diteliti. Atau hipotesis yang diajukan dapat diterima atau proses rekrutmen dan seleksi mempunyai pengaruh yang positif dan signifikan terhadap kinerja karyawan di PT. Dian Bahari Sejati.

Kata Kunci : Proses Rekrutmen, Seleksi dan Kinerja

(C) 2019 Jurnal Riset Inspirasi Manajemen dan Kewirausahaan 


\section{PENDAHULUAN}

\section{Latar Belakang}

Pengelolaan Sumber Daya Manusia (SDM) merupakan hal yang penting dalam pencapaiaan tujuan. Umumnya pimpinan perusahaan mengharapkan kinerja yang baik dari masingmasing karyawan dalam mengerjakan tugas-tugas yang diberikan oleh perusahaan. Perusahaan menyadari bahwa Sumber Daya Manusia (SDM) merupakan modal dasar dalam proses pembangunan perusahaan bahkan nasional, oleh karena itu kualitas SDM senantiasa harus dikembangkan dan diarahkan agar tercapainya tujuan yang telah ditetapkan oleh perusahaan. Oleh karena itu suatu perusahaan untuk mencapai kinerja yang optimal sesuai dengan harapan harus membuat suatu perencanaan sumber daya manusia, pengadaan, pengarahan, pengembangan, pemeliharaan, dan pemberhentian. Agar pengelolaan sumber daya manusia dapat berjalan secara efektif dan efisien.

Rekrutmen merupakan suatu perencanaan awal yang membantu perusahaan untuk memperoleh karyawan yang berkualitas dan kompeten dibidangnya, sehingga dapat meminimalisasi kecelakaan kerja dan pencapaian kinerja sesuai dengan harapan dan dapat direalisasikan dengan baik. Pelaksanaan rekrutmen juga akan membantu perusahaan untuk menempatkan karyawan yang tepat pada posisi yang tepat pula atau "the Right Man on The Right Place", sehingga tujuan dan harapan perusahaan dapat direalisasikan dengan baik, hal ini menjadi pegangan bagi para manajer dalam menempatkan tenaga kerja yang ada di perusahaannya.

Rekrutmen merupakan serangkaian aktivitas untuk mencari dan memikat pelamar kerja dengan motivasi, kemampuan, keahlian dan pengetahuan yang diperlukan guna menutupi kekurangan yang diidentifikasi dalam perencanaan kepegawaian. Sedangkan seleksi merupakan proses pemilihan dari sekelompok pelamar atau orang-orang yang memenuhi kriteria untuk menempati posisi yang tersedia berdasarkan kondisi yang ada pada perusahaan

Pengelolaan sumber daya manusia sangat diperlukan untuk efektivitas sumber daya manusia dalam suatu organisasi. Tujuan dari hal tersebut adalah untuk memberikan kepada organisasi satuan kerja yang efektif untuk mencapai tujuan studi tentang manajemen perusahaan bagaimana seharusnya perusahaan dapat mengembangkan, menggunakan dan memelihara karyawan dalam kualitas dan kuantitas yang tetap. Oleh karena itu pihak manajemen perusahaan harus mampu memahami bagaimana cara terbaik dalam mengelola karyawan yang berasal dari latar belakang, keahlian, dan kemampuan yang berbeda- beda sehingga karyawan dapat bekerja sesuai dengan keahlian dan jenis pekerjaan yang diberikan.

PT. Dian Bahari Sejati adalah suatu perusahaan yang bergerak di bidang jasa pelayaran yang memerlukan Sumber Daya Manusia yang handal dan kompeten sebagai faktor pengungkit untuk keunggulan bersaing PT. Dian Bahari Sejati, sehingga pengembangan kompetensi sumber daya manusia merupakan salah satu faktor kunci keberhasilan untuk pencapaian visi dan misi PT. Dian Bahari Sejati. Sejalan dengan visi, misi, dan strategi perusahaan untuk menjadi perusahaan kelas dunia di bidang jasa pelayaran, perlu diterapkan upaya yang lebih fokus dalam pengembangan SDM secara konsisten dan terus menerus.

\section{KAJIAN LITERATUR}

\section{Kinerja Karyawan}

Kinerja merupakan hasil kerja yang dicapai oleh karyawan dalam perusahaan dan diukur dengan target yang telah direncanakan dengan hasil kerja yang akurat serta tepat untuk dapat memperoleh hasil yang semaksimal mungkin, sehingga pekerjaan yang akan dilaksanakan harus benar-benar dilaksanakan sepenuhnya sebagai rasa tanggung jawab yang sebaik-baiknya. Oleh karena itu dapat disimpulkan bahwa kinerja sumber daya manusia adalah prestasi kerja atau hasil kerja (output) baik kualitas maupun kuantitas yang dicapai sumber daya manusia persatuan periode waktu dalam melaksanakan tugas kerjanya sesuai dengan tanggung jawab yang diberikan kepadanya.

Penilaian kinerja karyawan merupakan sarana untuk memperbaiki mereka yang tidak melakukan tugasnya dengan baik di dalam organisasi. Banyak organisasi berusaha mencapai sasaran suatu kedudukan yang terbaik dan terpercaya dalam bidangnya. Untuk itu sangat dibutuhkan pengembangan untuk meningkatkan kemampuan karyawan agar kinerja karyawan meningkat sehingga mereka dapat mencapai tujuan yang diharapkan. Peningkatan kinerja akan dapat tercapai apabila perusahaan juga akan memperhatikan sistem kesejahteraan dan pengembangan untuk meningkatkan kemampuan karyawan sehingga peningkatan kinerja sesuai dengan harapan.

\section{Rekrutmen}

Rekrutmen merupakan masalah yang penting bagi perusahaan dalam hal pengadaan tenaga kerja. Jika suatu rekrutmen berhasil dengan kata lain banyak pelamar yang memasukkan lamarannya, maka peluang perusahaan untuk mendapatkan karyawan yang terbaik akan menjadi semakin terbuka lebar, karena perusahaan akan memiliki 
banyak pilihan yang terbaik dari para pelamar yang ada.

Rekrutmen merupakan suatu keputusan perencanaan manajemen sumber daya manusia mengenai jumlah karyawan yang dibutuhkan, kapan diperlukan, serta kriteria apa saja yang diperlukan dalam suatu organisasi. Rekrutmen pada dasarnya merupakan usaha untuk mengisi jabatan atau pekerjaan yang kosong di lingkungan suatu organisasi atau perusahaan, untuk itu terdapat dua sumber sumber tenaga kerja yakni sumber dari luar (eksternal) organisasi atau dari dalam (internal) organisasi.

Penarikan (rekrutmen) pegawai merupakan suatu proses atau tindakan yang dilakukan oleh organisasi untuk mendapatkan tambahan pegawai melalui beberapa tahapan yang mencakup identifikasi dan evaluasi sumber-sumber penarikan tenaga kerja, menentukan kebutuhan tenaga kerja, proses seleksi, penempatan, dan orientasi tenaga kerja. Penarikan pegawai bertujuan menyediakan pegawai yang cukup agar manajer dapat memilih karyawan yang memenuhi kualifikasi yang mereka perlukan (Malthis \& Jackson 2011).

Rekrutmen yang efektif memerlukan tersedianya informasi yang akurat dan berkesinambungan mengenai jumlah dan kualifikasi individu yang diperlukan untuk melaksanakan berbagai pekerjaan dalam organisasi. Aktivitas rekrutmen akan menyisihkan pelamar yang kurang tepat dan memfokuskan upayanya pada calon yang akan dipanggil kembali. Aktivitas rekrutmen dapat membangun opini publik yang menguntungkan dengan cara mempengaruhi sikap para pelamar sedemikian rupa, terlepas mereka diangkat atau tidak.

\section{Seleksi}

Seleksi merupakan bagian materi dari operasional manajemen sumber daya manusia yaitu pengadaan (procurement), sedangkan pengadaan itu sendiri terdiri dari : perencanaan, perekrutan, seleksi, penempatan, dan produksi. Proses seleksi merupakan tahap-tahap khusus yang digunakan untuk memutuskan pelamar mana yang akan diterima. Proses tersebut dimulai ketika pelamar kerja dan diakhiri dengan keputusan penerimaan. Proses seleksi merupakan pengambilan keputusan bagi calon pelamar untuk diterima atau tidak.

\section{METODE PENELITIAN}

\section{Kerangka Konseptual Penelitian}

Pelaksanaan rekrutmen yang sesuai dengan perencanaan sumber daya manusia (MSDM) yang dibuat oleh perusahaan akan membantu perusahaan untuk mengetahui posisi yang akan direkrut, proses seleksi dibuat untuk memperoleh karyawan yang berpotensi dan tepat untuk menduduki posisi yang luang, dan pengembangan yang dilakukan oleh perusahaan akan membantu peningkatan skill dan kemampuan karyawan sehingga kinerja dan prestasi mereka meningkat dan tujuan perusahaan dapat direalisasikan dengan baik.

Pengaruh proses rekrutmen dan seleksi terhadap kinerja karyawan studi kasus di PT. Dian Bahari Sejati dapat dilihat pada gambar paradigma dibawah ini :

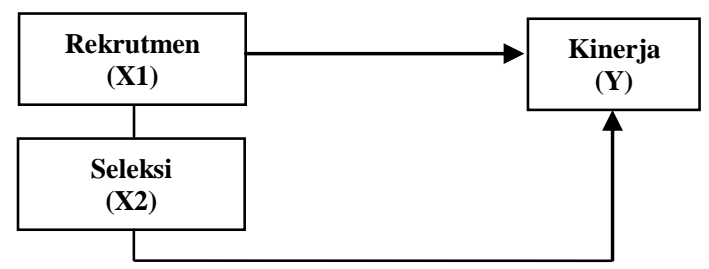

\section{Gambar Kerangka Konseptual Penelitian}

\section{Hipotesis}

Hipotesis ini masih perlu dianalisa lebih lanjut lagi kebenarannya, dengan mengadakan analisis atau penelitian, hipotesis ini kesimpulannya dapat diterima atau tidak sebagai teori empirik

Dari kerangka konseptual diatas dapat dibuat hipotesis sebagai berikut:

1. Diduga proses rekrutmen dan seleksi berpengaruh signifikan terhadap kinerja karyawan di PT. Dian Bahari Sejati.

2. Diduga seleksi berpengaruh dominan terhadap kinerja karyawan di PT. Dian Bahari Sejati.

\section{Rancangan Penelitian}

Racangan penelitian yang digunakan peneliti adalah : Studi kasus. Kasus artinya kejadian / peristiwa. Studi kasus berarti penelitian terhadap suatu kejadian atau peristiwa ini hendaknya tidak di artikan sebagai kejadian atau peristiwa biasa, yang menurut konsep bahasa inggris di sebut event. Suatu kejadian atau peristiwa yang mengundang masalah atau perkara, sehingga perlu ditelaah kemudian dicarikan cara penanggulangannya, antara lain melalui penelitian, seperti studi kasus yang dilakukan oleh perusahaan untuk memperoleh karyawan yang tepat melalui proses rekrutmen dan seleksi guna meningkatkan kinerja karyawan.

\section{Populasi dan Sampel}

Populasi dalam penelitian ini adalah seluruh karyawan yang ada pada PT. Dian Bahari Sejati, Bagian MSDM dengan demikian jumlah populasi sebanyak 123 orang untuk seluruh bagian yang ada dalam perusahaan.

Teknik pengambilan sampel yang digunakan adalah random sampling yang merupakan suatu cara mengambil sampel denngan tidak memilihmilih individu yang akan dijadikan responden. Seluruh individu dalam populasi diberi kesempatan yang sama untuk dijadikan responden. Sampel yang 
dipilih dengan cara demikian disebut simple random sample.

Selanjutnya jika jumlah subjeknya besar dapat diambil antara $10-25 \%, 30-45 \%$ atau lebih, tergantung setidak-tidaknya dari kemampuan peneliti dilihat dari waktu, tenaga, dan dana. Sempit luasnya wilayah pengamatan dari setiap subjek, karena hal ini menyangkut banyak sedikitnya data. Besar kacilnya resiko yang ditanggung oleh peneliti. Untuk penelitian yang resikonya besar, tentu saja jika sampel besar, hasilnya akan lebih baik. Berdasarkan keterangan diatas, maka sampel yang diambil sebanyak $25 \%$ dari jumlah populasi yaitu sebanyak 31 orang.

\section{Teknik Analisa Data}

Penelitian ini bertujuan menguji dan menganalisis hubungan kausal antara variabel bebas dan variabel terikat, sekaligus memeriksa validitas dan reliabilitas instrument penelitian secara keseluruhan. Oleh karena itu digunakan teknik analisis Regresi linear berganda menggunakan software SPSS versi 19.

Model analisis Regresi Linear Berganda yang digunakan Hair, et al. (2010) adalah sebagai berikut:

$$
\mathbf{Y}=\boldsymbol{\alpha}+\boldsymbol{\beta} \mathbf{X}_{1}+\boldsymbol{\beta} \mathbf{X}_{2}+\mathbf{e}_{\mathbf{i}}
$$

Keterangan :

$$
\begin{array}{ll}
\mathrm{Y} & =\text { Kinerja Karyawan } \\
\mathrm{X}_{1} & =\text { Rekrutmen } \\
\mathrm{X}_{2} & =\text { Seleksi } \\
\alpha & =\text { Konstanta } \\
\beta & =\text { Koefesien } \\
\mathrm{e}_{\mathrm{i}} & =\text { Error Term }
\end{array}
$$

\section{HASIL PENELITIAN DAN PEMBAHASAN}

\section{Hasil Validitas dan Reliabilitas}

Dari 58 daftar pertanyaan (Questioner) yang dijawab dan dikembalikan responden, penulis menginput nilai-nilai untuk bahan penguji. Uji validitas yang digunakan dalam penelitian ini adalah uji validitas butir. Menurut Ghozali (2010, hal. 45), uji signifikansi dilakukan membandingkan nilai $r_{\text {hitung }}$ dengan $r_{\text {tabel }}$. Jika nilai $r_{\text {hitung lebih }}$ besar dari nilai $r_{\text {tabel }}$ dan nilai positif maka butir atau indikator tersebut dinyatakan valid. Begitu juga sebaliknya Jika $\mathrm{r}_{\text {hitung }}$ lebih kecil dari $\mathrm{r}_{\text {tabel }}$ dan nilai negatif maka butir atau indikator tersebut dinyatakan invalid.

Berdasarkan hasil pengolahan data yang dilakukan maka diketahui bahwa seluruh item pertanyaan yang diajukan dinyatakan valid. Dari semua butir pertanyaan untuk masing-masing variabel proses rekrutmen, seleksi dan kinerja karyawan $\left(\mathrm{X}_{1}, \mathrm{X}_{2}\right.$, dan $\left.\mathrm{Y}\right)$ yang diuji, ternyata semua butir pertanyaan mempunyai status valid.
Selanjutnya butir instrumen yang valid di atas diuji reliabilitasnya, pengujian reliabilittas dilakukan dengan menggunakan Cronbach Alpha. Menurut Ghozali (2010: 47), reliabel cukup baik apabila hasil Alpha $\geq 0,3$, hasilnya seperti ditunjukkan dalam tabel berikut ini:

\begin{tabular}{lcl}
\multicolumn{1}{c}{ Variabel } & $\begin{array}{r}\text { Cronbach } \\
\text { Alpha }\end{array}$ & Status \\
\hline Proses Rekrutmen & 0,812 & Reliabel \\
\hline Seleksi & 0,786 & Reliabel \\
\hline Kinerja karyawan & 0,877 & Reliabel
\end{tabular}

Dari tabel di atas maka dapat diketahui bahwa realibilitas instrumen proses rekrutmen (PR) (variabel $\mathrm{X}_{1}$ ) sebesar 0,812 (reliabel), instrumen seleksi perusahaan $(\mathrm{S})$, (variabel $\mathrm{X}_{2}$ ) sebesar 0,877 (reliabel), dan instrumen kinerja Karyawan (Y) (variabel Y) sebesar 0,887 (realibel). Jika nilai reliabilitas semakin mendekati 1 , maka instrumen penelitian semakin baik. Nilai reliabilitas instrumen di atas menunjukkan tingkat reliabilitas instrumen penelitian yang memadai karena $>0,30$ ).

\section{Hasil Uji Statistik Deskriptif}

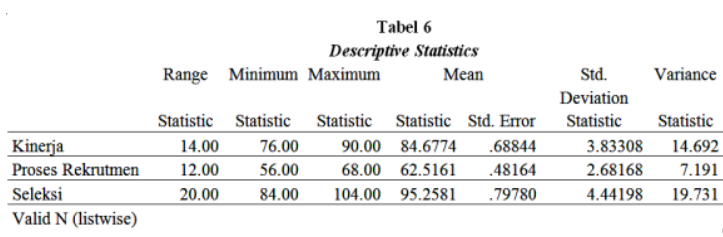

Berdasarkah hasil data diatas maka diketahui bahwa proses rekrutmen sangat penting dilakukan untuk memperoleh karyawan yang handal sesuai dengan bidangnya masing-masing dan proses rekrutmen akan membantu pihak perusahaan untuk memperoleh karyawan yang profesioanl sesuai dengan harapan perusahaan. Berdasarkan hasil deskriftif data di atas maka diketahui bahwa seleksi yang dilakukan oleh perusahaan sangat dominan akan mempengaruhi kinerja karyawan pada saat mereka telah bergabung dalam perusahaan, proses seleksi juga akan menentukan karyawan yang tepat dan profesional untuk menduduki posisi yang ditawarkan oleh perusahaan,sehingga memiliki pengaruh yang besar terhadap hasil kinerja perusahaan dimasa mendatang.

\section{Hasil Uji Asumsi Klasik}

Untuk menghasilkan suatu model yang baik, analisis regresi memerlukan pengujian asumsi klasik sebelum melakukan pengujian hipotesis. Apabila terjadi penyimpangan dalam pengujian asumsi klasik perlu dilakukan perbaikan terlebih dahulu, pengujian asumsi klasik tersebut meliputi uji normalitas, uji multikolonieritas, uji heteroskedasitas dan uji autokorelasi. 


\section{Uji Normalitas}

Pengujian ini bertujuan untuk menguji apakah dalam model regresi, variabel dependen (terikat) dan variabel independen (bebas) keduanya mempunyai distribusi normal atau tidak. Uji statistik yang dapat digunakan untuk menguji apakah residual berdistribusi normal adalah uji statistik non parametik Kolmogorov-Smirnov (K-S) dengan membuat hipotesis sebagai berikut:

$\mathrm{H}_{0}=$ Data residual berdistribusi normal

$\mathrm{H}_{\mathrm{a}}=$ Data residual tidak berdistribusi normal

Apabila nilai signifikansi lebih besar dari 0,05 maka $\mathrm{H}_{0}$ diterima dan $\mathrm{H}_{\mathrm{a}}$ ditolak, sebaliknya jika nilai signifikasi lebih kecil dari 0,05 maka $\mathrm{H}_{0}$ ditolak dan $\mathrm{H}_{\mathrm{a}}$ diterima.

Tabel

Descriptives

One-Sample Kolmogorov-Smirnov Test

\begin{tabular}{llr} 
& & \multicolumn{1}{c}{$\begin{array}{c}\text { Unstandardized } \\
\text { Residual }\end{array}$} \\
\hline $\mathrm{N}$ & Mean & 31 \\
\hline Normal Parameters $^{\mathrm{a}}$ & Std. Deviation & 2.6816887 \\
\hline Most Extreme Differences & Absolute & .495 \\
\cline { 2 - 3 } & Positive & .041 \\
\cline { 2 - 3 } & Negative &. .012 \\
\hline Kolmogorov-Smirnov Z & & .9600 \\
\hline Asymp. Sig. (2-tailed) & & \\
a. Test distribution is Normal. &
\end{tabular}

Dari hasil pengolahan data maka diketahui bahwa hasil pengujian statistik Kolmogorov-Smirnov (K-S) sebesar 0,726 dan sginifikasi pada 0,968 . Nilai signifikansi lebih besar dari 0,05 maka $\mathrm{H}_{0}$ diterima yang berarti data residual berdistribusi normal.

\section{Uji Multikolonieritas}

Uji multikolonieritas bertujuan untuk menguji apakah terdapat korelasi antar variabel independen dalam model regresi. Jika pada model regresi terjadi multikolineritas, maka koefisien regresi tidak dapat ditaksir dan nilai standard error menjadi tidak terhingga. Untuk melihat ada atau tidaknya multikolinieritas dalam model regresi dapat dilihat dari :

1). Nilai tolerance dan lawannya.

2). Variance Inflation factor (VIF)

Kedua ukuran ini menunjukan setiap variabel independen manakah yang dijelaskan oleh variabel independen lainnya. Tolerance mengukur variablitas variabel independen yang terpillih yang tidak dijelaskan oleh variabel independen lainnya. Jadi nilai tolerance yang rendah sama dengan nilai VIF yang tinggi (karena VIF =1/tolerance). Nilai cut off yang umum dipakai untuk menunjukan adanya multikolineritas adalah nilai tolerance $<0,10$ atau sama dengan VIF $>10$. Hasil dari uji multikolinieritas dapat dilihat pada tabel dibawah ini:

Tabel

Hasil Uji Multikolinieritas

Coefficients $^{a}$

Model

Coefficient Statistic

\begin{tabular}{crcc} 
& & Tollerance & VIF \\
\hline Part 1 & (Constant) & & \\
\hline Proses Rekrutmen & .727 & 2.86080 \\
\hline Seleksi & .528 & 2.88458
\end{tabular}

Dependen Variabel : Kinerja Karyawan

Berdasarkan hasil pengolahan data maka diketahui bahwa tidak terjadi gejala multikolineritas atara variabel independen yang di indikasikan dari nilai tolerance setiap variabel independen lebi besar dari 0,1 dan nilai VIF lebih kecil dari 10 maka dapat disimpulkan bahwa analisis lebih lanjut dapat dilakukan dengan menggunakan regresi berganda.

\section{Uji Heteroskedastisitas}

Uji Heteroskedastisitas bertujuan menguji apakah dalam model regresi terjadi ketidaksamaan variance dari residual satu pengamatan ke pengamatan yang lain. Model regresi yang baik adalah tidak terjadi Heteroskedastisitas. Cara mendeteksi ada atau tidaknya heteroskedastisitas adalah dengan melihat grafik plot antara nilai prediksi variabel dependen. Dasar analisis untuk menentukan ada atau tidaknya heteroskedastisitas yaitu:

a. Jika ada pola tertentu seperti titik - titik yang membentuk pola tertentu yang teratur (bergelombang, melebar kemudian menyempit), maka mengidentifikasikan telah terjadinya heteroskedastisitas.

b. Jika tidak ada pola yang jelas, serta titik titik menyebar diatas dan dibawah angka 0 pada sumbu Y, maka tidak terjadi heteroskedastisitas

Berdasarkan hasil pengolahan data maka diperoleh hasil bahwa scatterplot terlihat bahwa jika tidak ada pola yang jelas, serta titik-titik menyebar diatas dan dibawah angka 0 pada sumbu Y, maka mengidentifikasikan tidak terjadi heteroskedastisitas pada model regresi sehingga model regresi layak dipakai untuk melihat peningkatan kinerja karyawan di PT. Dian Bahasi Sejati berdasarkan masukan variabel proses rekrutmen dan seleksi. 


\section{Uji Auto Korelasi}

Berdasarkan pengujian autokorelasi bertujuan untuk menguji apakah terhdap korelasi antara kesalahan pengganggu pada suatu periode dengan kesalahan penganggu periode sebelumnya dalam model regresi. Jika terjadi autokorelasi dalam model regresi berarti koefisien korelasi yang diperoleh menjadi tidak akurat, sehingga model regresi yang baik adalah model regresi yang bebas dari autokorelasi. Cara yang dapat dilakukan untuk mendeteksi ada tidaknya autukorelasi adalah dengan melakukan pengujian durbin waston $(\mathrm{D}-\mathrm{W})$.

Kriteria untuk penilaian terjadinya autokorelasi yaitu:

1) Jika $0<\mathrm{d}<\mathrm{dl}$, berarti ada autokorelasi positif

2) Jika $4-\mathrm{dl}<\mathrm{d}<4$ berarti ada autokorelasi negatif

3) Jika $2<$ d $<4-$ du $<2<$ berarti tidak ada autokorelasi positif atau negatif

4) Jika dl $\leq$ d $\leq$ atau $4-$ dU $\leq$ d U $\leq$ d $\leq 4-$ $\mathrm{dL}$, pengujian tidak meyakinkan

Dari hasil tabel diatas maka diketahui bahwa hasil nilai Durbin- Weston yang didapat sebesar 1,097 yang berarti termasuk pada kreteria ketiga, sehingga dapat disimpulkan bahwa model regresi bebas dari masalah autokorelasi.

\section{Uji Signifikansi Simultan (Uji F)}

Uji statistik F dilakukan untuk menguji apakah variabel bebas (X) secara bersamasama / simultan mempunyai pengaruh yang signifikan atau tidak terhadap variabel terikat (Y). Bentuk kreteria pengujian adalah sebagai berikut:

Ho = tidak ada pengaruh proses rekrutmen $\left(\mathrm{X}_{1}\right)$, seleksi $\left(\mathrm{X}_{2}\right)$ terhadap kinerja karyawan pada PT. Dian Bahari Sejati.

$\mathrm{Ha}=$ ada pengaruh proses rekrutmen $\left(\mathrm{X}_{1}\right)$, seleksi $\left(\mathrm{X}_{2}\right)$ terhadap kinerja karyawan pada PT. Dian Bahari Sejati.

Kriteria pengujian :

a. Tolak Ho apabila $F$ hitung $>F_{\text {tabel }}$ atau $-\mathrm{F}$ hitung $<-\mathrm{F}_{\text {tabel }}$

b. Terima Ho apabila $\mathrm{F}_{\text {hitung }}<\mathrm{F}_{\text {tabel }}$ atau $-\mathrm{F}$ hitung $>-\mathrm{F}_{\text {tabel }}$

Berdasarkan hasil pengolehan data dengan program SPSS versi 20 maka diperoleh hasil sebagai berikut:

Tabel Uji F

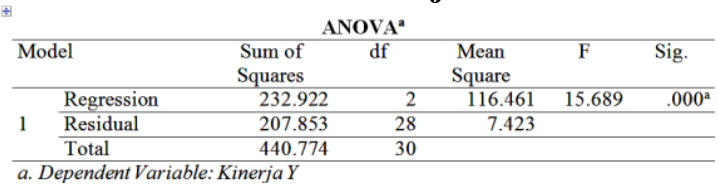

Dari hasil uji ANOVA (Analysis of variance) pada tabel diatas di dapat diperoleh hasil nilai $\mathrm{F}_{\text {hitung }}$ pada tabel di atas adalah 15.689 dengan tingkat signifikan sebesar 0,000 sedangkan F-tabel sebesar 7,423. Berdasarkan hasil tersebut dapat diketahui bahwa $F_{\text {hitung }}>\mathrm{F}_{\text {tabel }}(15,689>7,423)$ Tolak $\mathrm{H}_{0}$ dan $\mathrm{H}_{\mathrm{a}}$ diterima. Jadi dapat disimpulkan bahwa variabel proses rekrutmen $\left(\mathrm{X}_{1}\right)$ dan seleksi $\left(\mathrm{X}_{2}\right)$ secara bersama-sama terdapat pengaruh yang signifikan terhadap kinerja karyawan (Y) di PT. Dian Bahari Sejati.

\section{Uji Koefisien Determinasi $\left(\mathbf{R}^{2}\right)$}

koefisien determinasi ini berfungsi untuk mengetahui persentase besarnya pengaruh variabel independen dan variabel dependen yaitu dengan mengkuadratkan koefisien yang ditemukan. Dalam penggunaanya, koefisien determinasi ini dinyatakan dalam persentase (\%). Untuk mengetahui sejauh mana kontribusi atau persentase pengaruh proses rekrutmen $\left(\mathrm{X}_{1}\right)$ dan seleksi $\left(\mathrm{X}_{2}\right)$ terhadap kinerja karyawan di PT. Dian Bahari Sejati dapat dilakukan melalui pengujian determinasi sebagai berikut:

Tabel

Uji Koefisien Determinasi $\left(\mathbf{R}^{2}\right)$

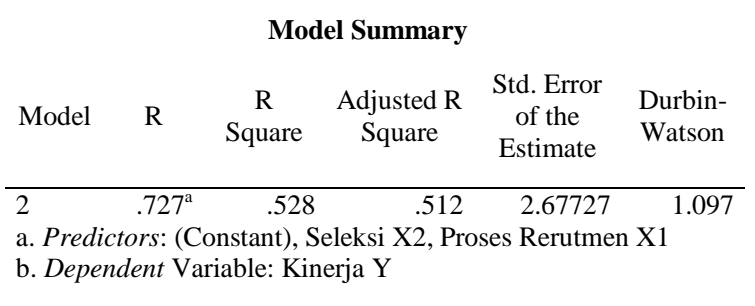

Pada tabel diatas dapat dilihat hasil analisis regresi secara keseluruhan menunjukan nilai $\mathrm{R}$ sebesar 0,727 menunjukan bahwa korelasi atau hubungan kinerja karyawan (variabel dependent) dengan proses rekrutmen dan seleksi (variabel independent) mempunyai tingkat hubungan yang kuat yaitu sebesar 72,7\%. Tingkat hubungan yang kuat ini dapat dilihat pada tabel pedoman untuk memberikan interprestasi koefisien korelasi.

\section{Hasil Uji Koefisien Regresi (Uji t)}

Uji statistik $t$ dilakukan untuk menguji apakah variabel bebas (X) secara individual mempunyai hubungan yang signifikan atau tidak terhadap variabel terikat (Y) untuk menguji signifikansi hubungan, digunakan rumus uji statistik $\mathrm{t}$ dengan tahap-tahap sebagai berikut:

a. Bentuk pengujian

$\mathrm{H}_{0}: \mathrm{r}_{\mathrm{s}}=0$ artinya tidak terdapat hubungan signifikan antara variabel bebas (X) dengan variabel terikat $(\mathrm{Y})$ 
$\mathrm{H}_{0}: \mathrm{r}_{\mathrm{s}} \neq 0$ artinya terdapat hubungan signifikan antara variabel bebas (X) dengan variabel terikat (Y)

b. Kriteria pengambilan keputusan

$\mathrm{H}_{0}$ diterima jika $\mathrm{t}_{\text {tabel }} \leq \mathrm{t}_{\text {hitung }} \leq \mathrm{t}_{\text {tabel }}$ pada $\alpha=5 \% \mathrm{df}=\mathrm{n}-\mathrm{k}$

$\mathrm{H}_{0}$ ditolak jika $\mathrm{t}_{\text {hitung }}>\mathrm{t}_{\text {tabel }}$ pada $\alpha=5 \%$ $\mathrm{df}=\mathrm{n}-\mathrm{k}$

Berdasarkan hasil pengolahan data maka diperoleh hasil masing - masing variabel maka diperolah hasil sebagai berikut :

a. Pengaruh Proses Rekrutmen terhadap Kinerja Karyawan pada PT. Dian Bahari Sejati

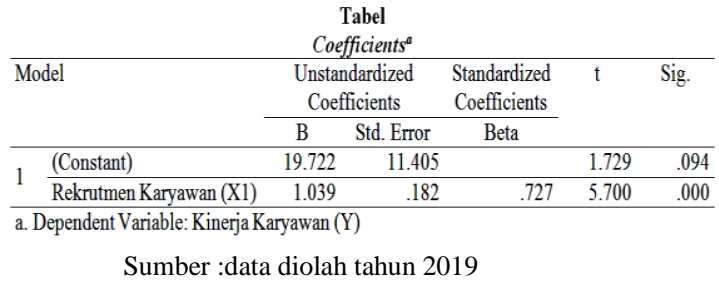

Berdasarkan hasil pengolahan data maka diketahui bahwa t hitung adalah sebesar 5,700 dengan siginifikan sebesar 0,000 sehingga diketahui bahwa proses rekrutmen yang adalah mempunyai pengaruh yang signifikan terhadap peningkatan kinerja karyawan di PT. Dian Bahari Sejati.

b. Pengaruh Seleksi terhadap Kinerja Karyawan pada PT. Dian Bahari Sejati Tabel

\begin{tabular}{|c|c|c|c|c|c|c|}
\hline & & & $\begin{array}{c}\text { Tabel } \\
\text { Coefficients }\end{array}$ & & & \\
\hline Mode & & Unstand & ardized & Standardized & $\mathrm{t}$ & Sig. \\
\hline & & $\mathrm{B}$ & Std. Error & Beta & & \\
\hline & (Constant) & 30.835 & 11.546 & & 2.671 & .012 \\
\hline 1 & $\begin{array}{l}\text { Seleksi } \\
\text { (X2) }\end{array}$ & .565 & .121 & .655 & 4.668 & .000 \\
\hline
\end{tabular}

a. Dependent Variable: Kinerja Karyawan (Y)

Sumber : Data diolah tahun 2019

Berdasarkan hasil pengolahan data maka diketahui bahwa t hitung adalah sebesar 4,668 dengan siginifikan sebesar 0,000 sehingga diketahui bahwa seleksi yang adalah mempunyai pengaruh yang signifikan terhadap peningkatan kinerja karyawan di PT. Dian Bahari Sejati. Berdasarkan hasil pengolahan data yang dilakukan oleh peneliti maka diketahui bahwa proses seleksi sangat pening untuk memperoleh karyawan yang professional, handal sesuai dengan bidang yang akan ditempatinya diperusahaan.

\section{PENUTUP}

\section{Kesimpulan}

Penelitian ini bertujuan untuk menguji pengaruh proses rekrutmen berdasarkan hasil penelitian dan seleksi terhadap kinerja karyawan di
PT. Dian Bahari Sejati. Penelitian ini juga menganalisis pengaruh variabel yang dominan (antara rekrutmen dan seleksi) terhadap kinerja karyawan studi dilakukan di PT. Dian Bahari Sejati.

Berdasarkan hasil analisis penelitian dapat disimpulkan bahwa rekrutmen dan keinginan berpengaruh terhadap kinerja, oleh karena itu proses rekrutmen dan seleksi dijalankan dengan baik maka perusahaan akan memperoleh karyawan yang tepat dan akan mampu meningkatkan kinerja mereka lebih baik lagi dari waktu ke waktu.

Hasil penelitian ini konsisten dengan hasil penelitian terdahulu yang menyatakan bahwa Kemudian penelitian yang dilakukan oleh Andika (2011) yang melakukan penelitian mengenai pengaruh rekrutmen terhadap kinerja karyawan pada PT. Perkebunan Nusantara III Medan. Dimana hasil analisis yang dilakukan menemukan bahwa perekrutan berpengaruh signifikan terhadap kinerja karyawan, sehingga dari hasil penelitian yang sebagaimana telah dilakukan, ternyata sistem rekrutmen yang dilakukan oleh PT. Angkasa Pura I Bandar Udara Hasanuddin berpengaruh positif dan signifikan terhadap kinerja karyawan. Dengan demikian dari hasil penelitian ini mendukung hipotesis yang telah diuraikan dan selain itu mendukung dari hasil penelitian yang sebagaimana telah dilakukan oleh peneliti sebelumnya.

Sedangkan Andhika (2011) yang menemukan ada pengaruh yang signifikan antara metode penarikan dan seleksi terhadap kinerja karyawan, dan selain itu Andhika menemukan bahwa proses seleksi merupakan variabel yang paling dominan mempengaruhi kinerja karyawan pada PT. Angkasa Pura I Bandar Udara Hasanuddin di Makassar, sehingga dari hasil pengujian yang telah dilakukan oleh peneliti ternyata seleksi karyawan berpengaruh positif terhadap kinerja karyawan khususnya pada PT. Angkasa Pura I Bandar Udara Hasanuddin, dengan demikian dari hasil penelitian ini mendukung penelitian sebelumnya.

\section{Saran}

Berdasarkan keterbatasan-keterbatasan yang ditemukan tersebut, maka saran-saran dapat diberikan adalah sebagai berikut:

1. Disarankan agar dalam menerapkan metode rekrutmen khususnya pada PT. Dian Bahari Sejati, hendaknya mempertahankan atau lebih mengembangkan metode rekrutmen yang selama ini diterapkan.

2. Disarankan agar perusahaan PT. Bahari Sejati, hendaknya lebih memperhatikan penerapan karyawan yang sesuai dengan kompetensi dimana setiap karyawan yang dimiliki dapat menyelesaikan atau menangani pekerjaan.

3. Penelitian selanjutnya hendaknya memperluas objek penelitian, tidak terbatas pada perusahaan manufaktur tetapi juga pada industri lain seperti Bank, Perusahaan jasa 
telekomunikasi dan penerbangan sehingga cakupan permasalahan menjadi luas dan dapat digeneralisasi.

4. Saran yang diberikan dalam penelitian ini yaitu : Pertama, dalam melakukan perekrutan karyawan hendaknya perusahaan berusaha dengan biaya yang serendah mungkin dengan menggunakan cara yang efektif dan efisien. Kedua, Pada saat melakukan seleksi karyawan perusahaan seharusnya lebih selektif dalam memilih karyawan dengan menambahkan test tertulis

5. untuk mengetahui potensi seseorang karyawan tersebut untuk ditempatkan dalam pekerjaan tertentu atau untuk dikembangkan. Ketiga, Dalam hal penempatan karyawan sebaiknya dilakukan orientasi dan sosialisasi untuk karyawan baru dan melakukan perkenalan dengan karyawan perusahaan di bagian yang terkait. Dengan adanya program orientasi ini diharapkan karyawan baru dapat mengenal lebih dalam tentang perusahaan mendalam atas hasil yang diperoleh.

6. Perlu dilakukan pengembangan instrumen penelitian, yaitu disesuaikan dengan kondisi dan lingkungan dari objek yang diteliti

\section{DAFTAR PUSTAKA}

Ambar Teguh Sulistiyani \& Rosidah, 2013, Manajemen Sumber Daya Manusia, Edisi Pertama, Cetakan Pertama Yogyakarta: Graha Ilmu.

Bambang Prasetyo \& Lina Miftahul Jannah, 2008, Metode Penelitian Kuantitatif, Teori dan Aplikasi, Jakarta: PT. Rajagrafindo Persada.

Dessler, Gary, 2006, Manajemen Sumber Daya Manusia, Jilid 1, Edisi Kesepuluh, Jakarta: PT. Indeks.

Erliana \& Mulyani, 2007, Pengolahan Data Dengan Menggunakan SPSS, Edisi Revisi, Cetakan kedua, Jakarta: Salemba Empat.

Ghozali Muhammad, 2011, Metodelogi Penelitian Bisnis, Edisi Revisi, Cetakan Kesembilan, Jakarta: PT. Raja Grasindo Persada.

Gomes Gerry Jhon, 2009, Manajemen Sumber Daya Manusia Manajemen Sumber Daya Manusia, Terjemahan Jimmy Sadeli dan Bayu Prawira Hie, Edisi Pertama, Cetakan Pertama, Yogyakarta: Graha Ilmu

Handoko T. Hani, 2008 Manajemen, Edisi Kedua, Cetakan Ketigabelas, Yogyakarta: BPFE.
Hasibuan Malayu, 2010, Manajemen Sumber Daya Manusia, Cetakan Kedelapan belas, Jakarta: Bumi Aksara.

Jogiyanto, 2010, Metode Penelitian Kuantitatif Kualitatif $R \& D, \quad$ Edisi Revisi, Jakarta: Salemba.

Mangkunegara, 2007 Manajemen Sumber Daya Manusia, Cetakan Pertama, Jakarta: Salemba Empat.

Moekijat, 2010, Manajemen Personalia, Edisi Revisi, Cetakan Kedelapan, Jakarta: Erlangga.

Nawawi Djumadi, 2008, Hukum Perburuan, Perjanjian Kerja, Cetakan Ketiga. Jakarta: PT. Raja Grafindo Persada.

Noe Gibson, James L, Donnelly JR, James, Ivancevich, John M. Alih Bahasa Zuhad Ichyauddin, 2007, Manajemen. Edisi Kesembilan, Jilid Pertama, Cetakan Kedua Jakarta: Erlangga.

Nuryanti, 2008, Manajemen Sumber Daya Manusia, Edisi Revisi, Cetakan Kelima, Jakarta: Salemba Empat.

Robert L Mathis \& Jonh H Jockson, 2012, Manajemen Sumber Daya Manusia, Terjemahan Jimmy Sadeli dan Bayu Prawira Hie, Buku 2 Edisi Pertama, Jakarta: Salemba.

Sedarmayanti, 2007, Manajemen Sumber Daya Manusia, Edisi Revisi, Cetakan Kedelapan, Jakarta: Salemba Empat.

Simamora Hendry, 2009, Manajemen Sumber Daya Manusia, Edisi Revisi, Cetakan Kelima, Jakart: Salemba Empat.

Sjafri Mangkuprawira \& Aida Vitayala Hubeis, 2007, Manajemen Mutu Sumber Daya Manusia, Cetakan Pertama, Bogor: Ghalia Indonesia.

Sugiyono, 2009, Metode Penelitian Bisnis, Edisi Revisi, Cetakan Ke Empat, Bandung: Alfabeta.

2010, Metodologi Penelitian Administrasi, Cetakan Ketujuh, Bandung: CV. Alfabeta.

Suharsimi, Arikunto, 2009, Prosedur Suatu Pendekatan Praktek, Edisi Revisi Keempat, Jakarta: PT. Rineka Cipta. 
Tjakrawala, 2008, Manajemen Personalia, Edisi Revisi, Cetakan Kedua, Jakarta: Salemba Empat.

Veithzal Rivai, 2010, Manajemen Personalia, Edisi Revisi, Cetakan Kelima, Jakarta: Salemba Empat.

\section{Profil penulis}

Muhammad Darwis Meyandie Nasution, Pascasarjana Universitas Merdeka Malang.

Email : darwis@ dianbaharisejati.com 